7. Минкомсвязь опубликовала проект закона о регулировании больших данных. [Электронный pecypc]. Режим доступа: https://digital.ac.gov.ru/news/4318/

8. Соснин К.А. Правовое регулирование больших данных: зарубежный и отечественный опыт // Журнал Суда по интеллектуальным правам. 2019. N 25. С.42.

9. Сосипатрова Е.Н. База данных как объект интеллектуальных прав: виды, критерии правовой охраны, режим использования данных [Электронный ресурс]. Режим доступа: https:// www.zakipp.unn.ru 9.-Sosipatrova.pdf (yandex.ru)

10. Тишина Ю., Шестоперов Д. С поправкой на большие данные // Газета «Коммерсантъ». 2020.21 февраля. № 32. С.7.

11. Трофимов О.И. Правовая охрана баз данных операторов электросвязи. Автореферат канд. дисс. M., 2008. C.11

\title{
Соколова А.А.
}

\section{Современные интернет-сервисы Мосбиржи для заключения и исполнения сделок} инвестирования в биржевые товары и ценные бумаги хозяйственных обществ

Волгоградский государственный университет (Россия, Волгоград)

doi: $10.18411 / \mathrm{lj}-08-2021-137$

\section{Аннотация}

В статье рассматриваются интернет - сервисы Московской биржи и возможности совершения сделок биржевыми товарами. Также отображены возможности инвестирования в заданном направлении и рассмотрен вопрос актуальности инвестирования в ценные бумаги.

Ключевые слова: инвестирование, цифровизация, биржа, электронная форма сделки, московская биржа, сделка.

\section{Abstract}

The article discusses the Internet services of the Moscow Stock Exchange and the possibility of making transactions in exchange-traded goods. The possibilities of investing in a given direction are also displayed and the issue of the relevance of investing in securities is considered.

Keywords: investment, digitalization, exchange, electronic form of transaction, Moscow exchange, transaction.

Фондовая биржа - это организованный и устойчиво функционирующий рынок ценных бумаг, которыми пользуются как предприятия, так и население. На бирже происходит оборот капиталовложений с помощью биржевых торгов. Оперативно протекающие биржевые процессы способны максимально эффективно отражаться в целом на экономическом развитии страны, делая биржу главным финансовым центром. Торги производятся регулярно в рамках законодательства РФ и соответствующими Правилами биржевой торговли. Организаторы на правах лицензии проводят закрытые аукционы, в которых принимают участие лица, которые подали заявки на приобретение биржевых активов. А также для принятия участия на биржевых торгах необходимо заключение договора между Биржей и пользователем. Московская биржа основана в 2011 году, после слияния ММВБ и РТС. В настоящее время ПАО Московская биржа является одной из наиболее стоящих организаций для инвесторов. Она вправе вносить изменения в условия настоящего Соглашения посредством опубликования текста измененной редакции настоящего Соглашения на Сайте по постоянному адресу https://www.moex.com. 
Биржа выступает организатором трейдинга акциями, валютой, производственными инструментами и облигациями. При этом купить и продать на ней также можно сахар, зерно, драгоценные металлы и инструменты денежного рынка.

Московская биржа это главная крупнейшая торговая площадка. Она осуществляет электронную торговлю на платформах OnlineBroker,_QUIK,_MetaTrader, Aton-Line,_Сбербанк Инвестор.

Также на ней размещены сервисы для заключения сделок это фондовый, срочный, денежный и валютный, а различаются они инструментами.

Свободный вход физическим лицам на Московскую биржу закрыт, обязательно нужен договор с брокером или получить статус квалифицированного инвестора. На сайте необходимо ознакомиться с пользовательским соглашением и подписать его. В графе «Частным инвесторам» есть описание технологии сотрудничества, предложены инструменты, календарь торгов. Необходимо получить персональный кабинет, а для этого заключить соглашение с брокером, получив логин и пароль. Юридическими лицами могут быть участники: брокеры, дилеры, управляющие, клиринговые организации, депозитарии, реестродержатели (регистраторы), банки, страховые компании, акционерные общества, на конец марта 2021 года их количество составляет 506.

По итогам мая 2021 мы видим, что общий объем торгов на рынках Московской биржи вырос на 22,5\% и составил 74,3 трлн. рублей (60,6 трлн рублей в мае 2020 года). Например, на валютном рынке произошло увеличение на 22,1\%.

АО «Национальная товарная биржа», являющаяся уполномоченной биржей Минсельхоза России и осуществляющая биржевые торги зерном и сахаром. Для работы с Московской биржей клиентам предоставляется удаленный информационный ресурс продуктов, а также помощь в решении возникших вопросов такого плана как, сервисы электронного документооборота, торговые терминалы, модуль расчета гарантийного обеспечения и т. п.

В России брокерская деятельность регулируется законодательно (ГК РФ, Закон о рынке ценных бумаг) и контролируется Центробанком. Также инвесторы опираются на Ф3 № 208-Ф3 от 26.12.1995 «Об акционерных обществах», что предусматривает защиту сделки в приобретении ценных бумаг.

Инвесторы, вкладывающие свои инвестиции в биржевую торговлю, должны быть уверены, что их права защищены и в данной деятельности отсутствует мошенничество. Инвестор, вкладывая свои сбережения в ценные бумаги, предполагает ликвидность, доходность, и защищенность вложений. Согласно ст. 2 Федерального закона от 21 ноября 2011 г. № 325-Ф3 «Об организованных торгах» биржевые торги действуют на основе законодательства. Мосбиржа это развивающийся сегмент на рынке с большим выбором активов как российских, так и зарубежных. В связи с этим Мосбиржа привлекает инвесторов своим разнообразием выбора.

У Мосбиржи число ее клиентов пусть медленно, но растет, что говорит о правильном направлении развития. Благодаря принятым законам, биржа защищена со стороны законодательства, что позволяет устойчиво развиваться.

Также невозможно не заметить развитие биржи в сторону зарубежных инвесторов. Для этого Московская биржа проводит торги с такой валютой как: евро, британский фунт, швейцарский франк, китайский юань, казахстанский тенге, турецкая лира - за доллары США. 19 ноября 2019 года Московская биржа подписала меморандум о взаимопонимании с китайской валютной торговой площадкой China Foreign Exchange Trade System (CFETS), направленный на укрепление сотрудничества и повышение ликвидности пары "китайский юань - российский рубль" на Московской бирже и CFETS. C этой целью уже созданная рабочая группа определит возможности 
взаимодействия и унификации процессов торговли в соответствии с регуляторными требованиями России и Китая.

"Московская Биржа" управляет единственной в России многофункциональной биржевой площадкой по торговле акциями, облигациями, производными инструментами, валютой, инструментами денежного рынка и товарами. В состав Группы входят центральный депозитарий (Небанковская кредитная организация акционерное общество "Национальный расчетный депозитарий"), а также клиринговый центр (Небанковская кредитная организация - центральный контрагент "Национальный Клиринговый Центр" (Акционерное общество)), выполняющий функции центрального контрагента на рынках, что позволяет Московской бирже оказывать клиентам полный цикл торговых и посттрейдинговых услуг.

Также Московская биржа подписала соглашения о сотрудничестве с инвестиционными платформами "Поток" и "Город Денег", и с управляющей компанией "Модернизация Инновации Развитие" (АО "МИР"), которые будут содействовать привлечению инвестиций компаниями малого и среднего предпринимательства (МСП). Инвестиционная платформа "Поток" работает с 2016 года и предоставляет возможность частным инвесторам выдавать займы малому бизнесу в России. Вадим Дубовик, генеральный директор АО "МИР", считает, что расширяя формы финансовой поддержки для финансирования платформ инвесторов, что будет прозрачность в использовании инвестиционной деятельности и снижены риски для инвесторов. Следовательно, для конкурентоспособной борьбы за деньги инвесторов торговые площадки должны постоянно адаптироваться к изменяющимся условиям и трендам на финансовом рынке. В области международного сотрудничества также Московская биржа расширяет свои позиции. Она участвует в международных бизнес ассоциациациях и позволяет бирже качественно оценивать уровень конкурентоспособности фондового рынка и приобретать ценный опыт международных торговых площадок.

Таким образом, современные интернет-сервисы для заключения и исполнения сделок инвестирования в биржевые товары и ценные бумаги Московская биржа диверсифицирует свои денежные доходы не только с помощью интеграции с другими институтами, непосредственно оказывающими услуги на рынке ценных бумаг, но и благодаря выполнению роли оператора финансовой платформы - совершенно нового вида не кредитных финансовых организаций. На сайте www.moex.com, можно ознакомиться только с общей информацией о торгах, законодательной базой, брокерах, а также посмотреть комиссии и расценки. А чтобы открыть счет, то это сделать самостоятельно не получится, и придется прибегнуть к услугам брокера. Где мы можем найти рейтинг брокеров с ним ознакомиться и выбрать уже для себя. То есть, по сути, сам сайт является посредником. Чтобы дальше развиваться, необходимо расширять и пополнять биржу новыми продуктами для привлечения большего количества инвесторов. Мосбиржа устойчиво развивающийся Российский биржевой холдинг, поэтому благодаря инвесторам ее сервисы будут развиваться.

$$
* * *
$$

1. Мехмонов С.У. Понятие и сущность фондовой биржи. Мировая наука. 2020. № 2(35)

2. Устав Публичного акционерного общества «Московская Биржа MMBБ-РTC»// URL: file://C:/Users/1/Desktop/MOEХ/УСТАВ\%20МОСКОВСКОЙ\%20БИРЖИ.pdf

3. Сычева А.А. Институциональная структура фондового рынка Российской Федерации // Актуальные проблемы российского права. 2015. № 2

4. Иванилова С.В. Биржевое дело : учеб. пособие. - 2-е изд., стер. - Москва: «Дашков и К», 2020. 222с

5. Сайт ОАО «Московская биржа» [Электронный ресурс]. - Режим доступа: http://moex.com 